\title{
Composting sewage sludge with green waste from tree pruning
}

\author{
Sarah Mello Leite Moretti ${ }^{1}$, Edna Ivani Bertoncini ${ }^{2 *}$, Cassio Hamilton Abreu-Junior ${ }^{1}$
}

${ }^{1}$ Center for Nuclear Energy in Agriculture - Dept. of Plant Mineral Nutrition, Av. Centenário, 303 -13400-070 -

Piracicaba, SP - Brazil.

${ }^{2}$ São Paulo's Agency for Agribusiness TechnologySecretariat of Agriculture and Food Supply of São Paulo State, Rod. SP 127, km 30, C.P. 28 - 13400-970 Piracicaba, SP - Brazil.

${ }^{*}$ Corresponding author <ebertoncini@apta.sp.gov.br>

Edited by: Leônidas Carrijo Azevedo Melo

\begin{abstract}
Sewage sludge (SS) has been widely used as organic fertilizer. However, its continuous use can cause imbalances in soil fertility as well as soil-water-plant system contamination. The study aimed to evaluate possible improvements in the chemical and microbiological characteristics of domestic SS, with low heavy metal contents and pathogens, through the composting process. Two composting piles were set up, based on an initial C/N ratio of 30:1, with successive layers of tree pruning waste and SS. The aeration of piles was performed by mechanical turnover when the temperature rose above $65^{\circ} \mathrm{C}$. The piles were irrigated when the water content was less than $50 \%$. Composting was conducted for 120 days. Temperature, moisture content, $\mathrm{pH}$, electrical conductivity (EC), carbon and nitrogen contents, and fecal coliforms were monitored during the composting. A reduction of $58 \%$ in the $\mathrm{EC}$ of the compost (SSC) compared with SS was observed and the $\mathrm{pH}$ reduced from 7.8 to 6.6. There was an increase in the value of cation exchange capacity/carbon content (CEC/C) and carbon content. Total nitrogen remained constant and $\mathrm{N}^{-\mathrm{NO}_{3}}+\mathrm{N}^{-} \mathrm{NH}_{4}{ }^{+}$were immobilised in organic forms. The $\mathrm{C} / \mathrm{N}$ ratio decreased from 25:1 to $12: 1$. Temperatures above $55^{\circ} \mathrm{C}$ were observed for 20 days. After 60 days of composting, fecal coliforms were reduced from $10^{7}$ Most Probable Number per gram of total solids (MPN $\mathrm{g}^{-1}$ ) to $10^{4} \mathrm{MPN} \mathrm{g}^{-1}$. I one pile the $10^{3} \mathrm{MPN} \mathrm{g}^{-1}$ reached after 90 days in one pile; in another, there was recontamination from $10^{5}$ to $10^{6} \mathrm{MPN} \mathrm{g}^{-1}$. In SSC, helminth eggs were eliminated, making application sustainable for agriculture purposes.

Keywords: biosolid, compost, pathogen, soil fertility
\end{abstract}

Received October 01, 2014

Accepted March 19, 2015 landfill and presents a high risk of spontaneous combustion. It is possible to obtain compost with moisture of around $30-40 \%$ that is free from pathogens, (European Commission, 2001). Thus, compost, when compared with sewage sludge, has a lower cost of transportation and presents a lower risk to public health.

The use of compost reduces the risks of environmental contamination as compared to the use of sewage sludge in nature, because it promotes decreases in the levels of heavy metals (Hua et al., 2009), reductions in the risk of nitrate leaching (Corrêa et al., 2006), and elimination of pathogens (Khalil et al., 2011). The humic substances formed during the composting process promote the building of soil fertility, and there is an actual increase in organic matter content in the soil, particularly in soil under tropical conditions, which is originally weathered and poor in organic matter (Bertoncini et al., 2008).

This study aimed to evaluate the efficiency of the composting process in improving the physico-chemical, chemical, and microbiological characteristics of sewage sludge treated aerobic-anaerobically. This was suggested to achieve reclassification of compost in Brazilian agricultural and environmental legislations and its safe and sustainable use in agricultural soils.

\section{Materials and Methods}

Chemical analysis of sewage sludge and tree prun-
ing waste
The sewage sludge used in the composting process was collected from the domestic sewage treatment plant in the city of Franca $\left(20^{\circ} 32^{\prime} 15^{\prime \prime} \mathrm{S}, 47^{\circ} 27^{\prime} 35^{\prime \prime} \mathrm{W}\right)$ in the 
state of São Paulo, Brazil. This sewage treatment plant treats sewage from 300,000 inhabitants through aerobic and anaerobic processes. To characterise the sewage sludge, samples were collected over several weeks and their water content, organic carbon, and total nitrogen were determined (Andrade and Abreu, 2006).

The water content was determined after drying in an oven with forced air circulation, at a temperature of 65 ${ }^{\circ} \mathrm{C}$ for $48 \mathrm{~h}$. This dry material was ground in a porcelain mortar, then the organic carbon content was extracted according to Walkley and Black (1934) by wet oxidation, with potassium dichromate $\left(1.25 \mathrm{~mol} \mathrm{~L}^{-1}\right)$ in an acid medium, hot, under reflux, and determined by titration with ferrous ammonium sulphate $\left(0.1 \mathrm{~mol} \mathrm{~L}^{-1}\right)$. For determination of total nitrogen content digestion with sulphuric acid in presence of a Raney's alloy was performed up to $350{ }^{\circ} \mathrm{C}$, followed by distillation of extract digested and titration (Andrade and Abreu, 2006). This methodology utilizes a catalyst which provides oxidation of organic matter, including those most recalcitrant, commonly present in organic wastes, such as sewage sludge and compost.

The vegetal material (tree pruning waste) used in the composting process was dried and ground, then the organic carbon content was determined according to Walkley and Black (1934), and the total nitrogen content was determined according to Sarruge and Haag (1974), methodology developed for vegetal materials, by digestion up to $350{ }^{\circ} \mathrm{C}$ with sulphuric acid, salts and catalysts $\left(\mathrm{Na}_{2} \mathrm{SeO}_{3}, \mathrm{Na}_{2} \mathrm{SO}_{4}, \mathrm{CuSO}_{4}\right)$, followed by distillation of extract digested, and titration.

From the values obtained for total carbon content, total nitrogen content and water content of sewage sludge and green waste from tree pruning, the proportion of each material needed in the composting piles to obtain an initial $\mathrm{C} / \mathrm{N}$ ratio of $30: 1$ and water content of around $50 \%$ was calculated.

Concomitantly, sewage sludge samples with approximately $1.0 \mathrm{~kg}$ material were collected for quantification of viable helminth eggs and protozoan cysts, according to Thomaz-Soccol et al. (2000), as well as for detection of Salmonella sp. and coliforms as determined by the United States Environmental Protection Agency (USEPA, 2003). The samples were incubated in a bacteriological incubator for $24 \mathrm{~h}$. After this period, the yellowish cells indicating the number of total or thermotolerant coliforms were counted, the number of fluorescent cells observed under a UV lamp provided the value of Escherichia coli, and the presence or absence of Salmonella sp.in the organic materials was verified.

A second sample was homogenized, and a part of this sample was separated, approximately $0.2 \mathrm{~kg}$, for the chemical analyses. The $\mathrm{pH}$ value of fresh materials was determined in the suspension using $0.01 \mathrm{~mol} \mathrm{~L}^{-1} \mathrm{CaCl}_{2}$ $(1: 5, \mathrm{w}: \mathrm{v})$, and electrical conductivity (EC) was determined in water $(1: 10, \mathrm{w}: \mathrm{v})$ after filtering the material (Andrade and Abreu, 2006).

The cation exchange capacity (CEC) was determined according to Williams (1984), and determination of heavy metals was performed according to the SW-846 3051 method (USEPA, 1994), followed by detection by inductively coupled plasma mass spectrometry (ICPMS). Organic matter content was determined using the loss in ignition method at $550{ }^{\circ} \mathrm{C}$, after initial drying of the material at $65{ }^{\circ} \mathrm{C}$, followed by drying at $110{ }^{\circ} \mathrm{C}$.

\section{Composting process and monitoring}

In July 2009, two composting piles were set up on a sealed patio in the Sewage Treatment Plant of Franca. The piles' dimensions were: $3 \mathrm{~m}$ wide $\times 6 \mathrm{~m}$ long $\times 1.7 \mathrm{~m}$ high, in successive layers of tree pruning waste and sewage sludge, totalling $15 \mathrm{t}$ of materials. For the start of the composting process, a $\mathrm{C} / \mathrm{N}$ ratio of 30:1 was used, considering the density of sewage sludge and tree pruning waste of 0.9 $\mathrm{t} \mathrm{m}^{-3}$ and $0.3 \mathrm{t} \mathrm{m}^{-3}$, respectively, as well as the organic carbon content, total nitrogen content, and water content of each material. From three days after installation of the composting piles, mechanical turnover was performed every time the temperature of the piles rose above $65^{\circ} \mathrm{C}$.

Daily monitoring of the temperature of the piles was performed using a metal stem with a digital thermometer $0.4 \mathrm{~m}$ high at five points on the composting piles. The average temperature of the piles was obtained. These data were used to verify the number of days on which the piles were subjected to temperatures above $55{ }^{\circ} \mathrm{C}$, and were taken as a basis for elimination of pathogens present in the sewage sludge, Brazilian environmental legislation (CONAMA, 2006b) assumes that the temperature should be above $40{ }^{\circ} \mathrm{C}$ for at least 14 days, and according to the USEPA (2003) the temperature should be maintained at $55{ }^{\circ} \mathrm{C}$ for 15 days in mechanical turning systems.

Water content was measured weekly, and irrigation was carried out when the water content was below $50 \%$ in the piles. In the first two months, when the temperatures were higher than $65^{\circ} \mathrm{C}$, the piles were turned mechanically by a wheel loader. After the thermophilic period, turning was carried out weekly. The composting process was terminated at 120 days when pile temperatures stabilized, and after this period (until 140 days) pile samples were collected for physico-chemical characterization in order to confirm the composting process had come to an end.

The piles were monitored fortnightly by sampling the material and determining water content, $\mathrm{pH}$ and $\mathrm{EC}$ values, organic carbon and total nitrogen content, using the methods mentioned above for sewage sludge analysis. At the end of the composting process, samples were taken from ten points in each pile, to form a composite sample. The $\mathrm{pH}$ of the fresh material was determined in $0.01 \mathrm{~mol}$ $\mathrm{L}^{-1} \mathrm{CaCl}_{2}(1: 5, \mathrm{w}: \mathrm{V})$, and $\mathrm{EC}$ values were determined in water $(1: 10, \mathrm{w}: \mathrm{v})$ (Andrade and Abreu, 2006). The $\mathrm{N}_{-} \mathrm{NO}_{3}^{-}$and $\mathrm{N}-\mathrm{NH}_{4}{ }^{+}$content was determined according to a modified method advocated by Gaines (1977) that uses trichloroacetic acid to $3 \%$ as an extraction solution to precipitate nitrogen protein forms and extract inorganic nitrogen forms $\left(\mathrm{N}-\mathrm{NO}_{3}{ }^{-}\right.$and $\mathrm{N}_{-} \mathrm{NH}_{4}{ }^{+}$. The filtered extract was distilled in the presence of Devarda's alloy, and $\mathrm{N}_{-} \mathrm{NO}_{3}$ and $\mathrm{N}_{-} \mathrm{NH}_{4}{ }^{+}$ content was determined by titration (AOAC, 1984). 
At $30,60,90$, and 120 days of the composting process, materials from the piles were sampled, and stored in sterilized polyethylene bags, for quantification of fecal coliform and E. coli. Also, in the final compost, helminth eggs, Salmonella sp., and protozoan cysts were quantified, according to the methods mentioned above for sewage sludge. Compost samples were dried at $65^{\circ} \mathrm{C}$, then the water content, organic carbon, total nitrogen, $\mathrm{Cu}$, As, $\mathrm{B}, \mathrm{Ba}, \mathrm{Cd}, \mathrm{Co}, \mathrm{Cr}, \mathrm{Hg}, \mathrm{Mn}, \mathrm{Mo}, \mathrm{Ni}, \mathrm{Pb}, \mathrm{Se}, \mathrm{Sb} \mathrm{Zn}$, and organic matter content, as well as the values of CEC were determined as mentioned above.

\section{Results and Discussion}

\section{Physico-chemical characterisation of sewage sludge} and sewage sludge compost

The water content in the compost produced was $58 \%$ (by weight), compared with the water content of $70 \%$ (by weight) in sewage sludge. In field conditions, this reduction in water content facilitates the operation of compost application, since application of sewage sludge is hampered by its high water content. In addition, the cost of transporting compost becomes cheaper than sewage sludge transportation, and thus, compost can be transported to areas more distant from its production centre.

The nitrogen content of the compost, however, was lower than that of the SS, which can be considered a negative point with regard to agricultural use of compost, because a larger amount of the compost could be necessary as compared to the sewage sludge in order to provide the amount of nitrogen needed for the crop, since, according to Brazilian environmental legislation (CONAMA, 2006a), the agricultural recommendation made should consider the nitrogen content present in these materials, and the amount of nitrogen recommended for the crop. The concept of increased economic radius of application due only to the reduction of water content is questionable, in this case. However, compost incorporates humic substances into the soil, thereby increasing the fertility of highly weathered soils in tropical conditions (Bertoncini et al., 2008).

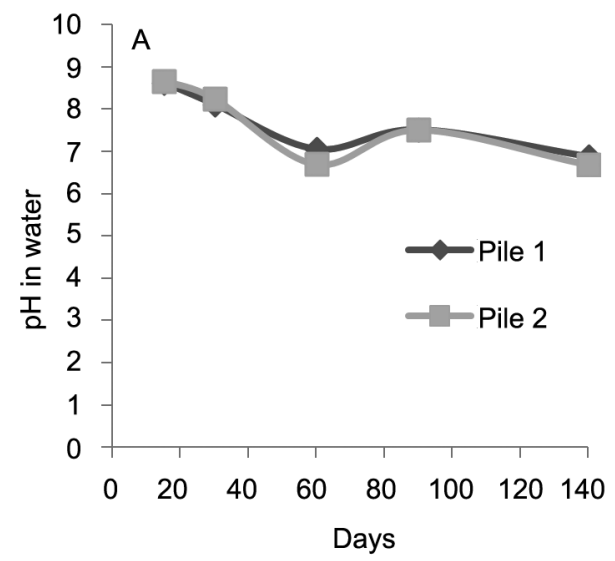

The electrochemical properties of the sewage sludge were improved throughout the composting process. The initial $\mathrm{pH}$ value of the mixture of sewage sludge and tree pruning waste was equal to 7.8 . The final $\mathrm{pH}$ value of the compost was 6.6 , which characterised mature composts; a $\mathrm{pH}$ value above 6.0 is required by Brazilian agricultural legislation (MAPA, 2009) that regulates compost for registration as fertiliser class D (from sanitary waste).

During the composting process there was a reduction in $\mathrm{pH}$ value over time (Figure 1), which stabilised at a value close to 6.6 , showing the various stages of the composting process, beginning with the decomposition of organic material by fungi and bacteria, a process through which organic acids are released and accumulate in the mixture. Lower $\mathrm{pH}$ values favor the succession of microorganism populations in the composted mass, and stimulate the growth of decomposers of cellulose and lignin, microorganisms that finish the decomposition process (Stentiford and Bertoldi, 2010; Khalil et al., 2011). Organic acids are completely oxidised, stabilising the $\mathrm{pH}$ value at the end of the composting process (Jouraiphy et al., 2005; Khalil et al., 2011).

The EC value of the sewage sludge was $1,887 \mathrm{mS}$ $\mathrm{cm}^{-1}$. The material collected in Pile 2 showed the highest values of $\mathrm{EC}\left(2,457 \mathrm{mS} \mathrm{cm}^{-1}\right)$ after 15 days, and the final value of the compost was $782 \mathrm{mS} \mathrm{cm}^{-1}$, representing a reduction of $58 \%$ as compared with fresh waste. The reasons for this reduction may be due to the formation of more stable bonds between the ions and organic matter during the composting process (humification phase) (Bertoncini et al., 2008), which reduce the solubility of the salts present in the compost. In addition, there is a reduction in salt concentration arising from the effect of dilution, due to the mixing of the bulking agent and the sewage sludge. This reduction in EC may translate to a lower risk of soil salinization.

The values of CEC were 380 and $195 \mathrm{mmol} \mathrm{kg}^{-1}$ and the values of CEC/C were 12 and 21 for sewage sludge and compost, respectively, indicating the contribution of the negative charges derived from organic ma-

\footnotetext{
Figure 1 - Change in pH values measured in water $(\mathrm{A})$ and $0.01 \mathrm{~mol} \mathrm{~L}^{-1} \mathrm{CaCl}_{2}(\mathrm{~B})$ during the composting process.
}

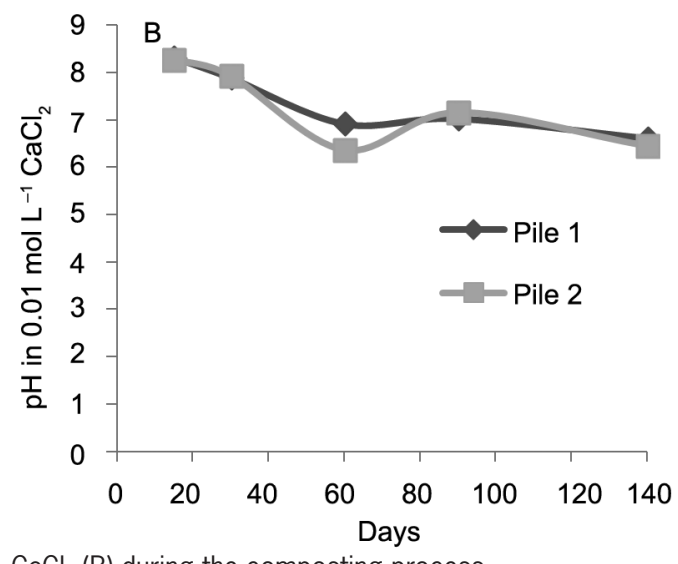


terial obtained during the composting process, probably via the humification process (Bertoncini et al., 2008).

The variation in the levels of organic matter, organic carbon, and total nitrogen during the composting process is shown in Figure 2. These levels were compared with the values required by legislation that regulates the registration of organic fertilisers as class $\mathrm{D}$ in Brazil (MAPA, 2009). The level of total $\mathrm{N}$ was constant during the process and was around $2 \%$ in the final compost, which is above the minimum value of $0.5 \%$, determined by Brazilian legislation.

At the beginning of the composting process, the $\mathrm{C} / \mathrm{N}$ ratio of the piles was equal to $25: 1$ and in the final compost it was around 12:1, below the maximum value of 20:1 allowed by Brazilian legislation. A similar result was obtained by Amir et al. (2005) that observed, after a process of composting sewage sludge with straw, a decrease in the $\mathrm{C} / \mathrm{N}$ ratio from 23.9 to 12.1 in the compost, reflecting the microbial decomposition and stabilization of organic matter.

The value of the $\mathrm{C} / \mathrm{N}$ ratio obtained at the beginning of the composting process (25:1) (Figure 2) differed from the value calculated initially (30:1), due to the losses of material, since the sewage sludge is pasty material and tends to be retained in the implement used to build compost piles. Carbon content was increased from 14 $\%$ in the sewage sludge to $19 \%$ in the final compost, which was higher than the minimum level established by Brazilian legislation of $15 \%$. Also, the value of organic matter content was increased from $10 \%$ in the sewage sludge to $18 \%$ in the compost (Table 1 ).

Organic carbon content was reduced from $23 \%$ after 21 days of the composting process to $19 \%$ at the end of the process, and organic matter content was reduced from $31 \%$ to $18 \%$ in the same period (Figure 2), due to

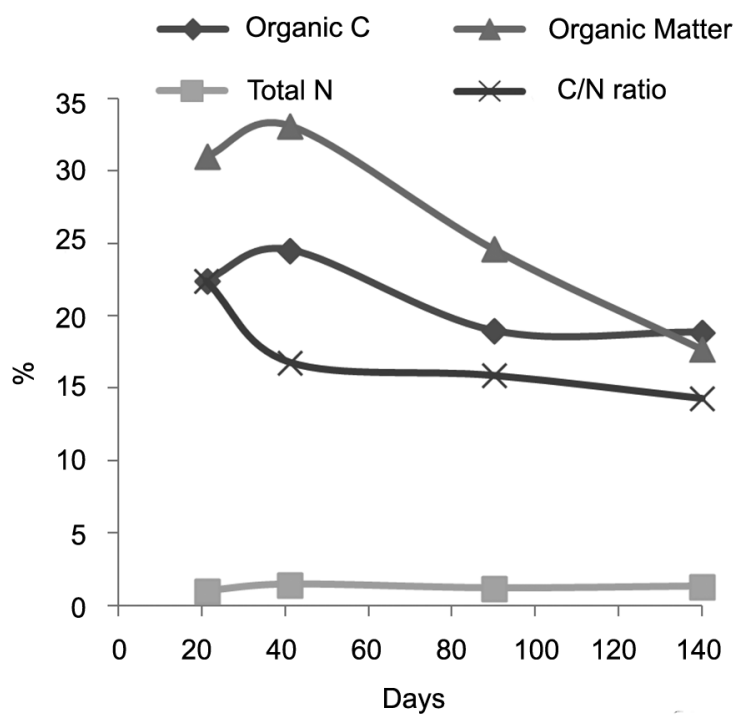

Figure 2 - Change in $\mathrm{C}, \mathrm{N}$, and organic matter contents and $\mathrm{C} / \mathrm{N}$ ratio during the composting process. losses by the reactions of decomposition and release of $\mathrm{CO}_{2}$ (Khalil et al., 2011). Hernández et al. (2006) studied the composting process of anaerobically-digested sewage sludge and anaerobically-digested sewage sludge mixed with two ratios of sawdust, and observed a large release of volatile organic matter during the initial period of the composting process, indicating mineralisation of more labile organic compounds. Hernández et al. (2006) also observed a reduction in the levels of $\mathrm{C}-\mathrm{CO}_{2}$ released from the composted mass at the end of the process, indicating the presence of more stable organic material formed during the humification phase, which was more resistant to degradation.

The chemical characterisation of sewage sludge and compost (Table 1) indicated an increase in potassium $(\mathrm{K})$ and calcium values $(\mathrm{Ca})$ in the compost, while phosphorus $(\mathrm{P})$ and magnesium values $(\mathrm{Mg})$ were constant. The low $\mathrm{K}$ content of the sewage sludge is noteworthy, because this element is very soluble in water and, therefore, $\mathrm{K}$ remains dissolved in wastewater during sewage treatment process. In the compost, there was an increase in $\mathrm{K}$ content due to the addition of structural materials, which provided a better nutritional balance in the organic fertiliser. Also, the Ca levels were higher in the plant material originating from tree pruning, providing an increase in $\mathrm{Ca}$ content in the compost.

The As, B, Ba, Cr, Cd, Cu, Hg, Mo, Ni, Pb, Se, $\mathrm{Sb}$, and $\mathrm{Zn}$ content of the sewage sludge and the compost are shown in Table 1. The levels were below those required by environmental Brazilian legislation (CONAMA, 2006a). In the compost, there was a reduction in the levels of these elements, and this may be due to the dilution effect deriving from the addition of the structural material, and/or by the retention processes of the metals with the humic substances produced during the composting process (Bertoncini et al., 2008). Also, the EPA 3051 uses only concentrated nitric acid, or alternatively, concentrated nitric acid and concentrated hydrochloric acid, leading to a pseudo-total content and not the total content. Amir et al. (2005) found a reduction in the overall levels of $\mathrm{Zn}, \mathrm{Pb}$, and $\mathrm{Cu}$ in compost, the amount of potentially bioavailable metals was less than $2 \%$, because metals were in more stable forms bound to humic substances present in compost.

Changes in the distribution of the forms of nitrogen in the sewage sludge and compost are presented in Figure 3. In the sludge, $60 \%$ of total $\mathrm{N}$ was found in organic form and $40 \%$ in mineral form $\left(\mathrm{N}-\mathrm{NO}_{3}{ }^{-}+\right.$ $\mathrm{N}-\mathrm{NH}_{4}{ }^{+}$), while for the compost of both piles, the distribution was $20 \%$ in mineral form and $80 \%$ in organic form. Amir et al. (2005) and Corrêa et al. (2006) indicated that the mineral- $\mathrm{N}$ released during organic matter decomposition was immobilised in organic forms of slow release into the soil, thereby reducing the risks of contamination of the groundwater with nitrates. 
Table 1 - Chemical and electrochemical characterisation of the sewage sludge and compost, and the limits of Brazilian Environmental legislation (CONAMA, 2006a).

\begin{tabular}{|c|c|c|c|}
\hline \multirow{2}{*}{ Attributes } & \multicolumn{3}{|r|}{ Values } \\
\hline & Sewage sludge & Compost & Brazilian Legislation of Environmental National Council (CONAMA)a \\
\hline $\mathrm{pH} 0.01 \mathrm{M} \mathrm{CaCl}_{2}$ & 7.8 & 6.5 & - \\
\hline Water content (\%) & 70 & 58 & - \\
\hline Electrical conductivity $\left(\mathrm{mS} \mathrm{cm}^{-1}\right)$ & 1,887 & 782 & - \\
\hline Organic matter (\%) & 10 & 18 & - \\
\hline C-total $\left(\mathrm{g} \mathrm{kg}^{-1}\right)$ & 140 & 190 & - \\
\hline N-total ( $\left.\mathrm{g} \mathrm{kg}^{-1}\right)$ & 35 & 18 & - \\
\hline$P\left(g ~ k g^{-1}\right)$ & 11 & 12 & - \\
\hline$K\left(\mathrm{~g} \mathrm{~kg}^{-1}\right)$ & 1 & 3 & - \\
\hline $\mathrm{Ca}\left(\mathrm{g} \mathrm{kg}^{-1}\right)$ & 14 & 21 & - \\
\hline $\operatorname{Mg}\left(\mathrm{g} \mathrm{kg}^{-1}\right)$ & 3 & 3 & - \\
\hline $\mathrm{S}\left(\mathrm{g} \mathrm{kg}^{-1}\right)$ & 9 & 5 & - \\
\hline $\mathrm{Cu}\left(\mathrm{mg} \mathrm{kg}^{-1}\right)$ & 202 & 152 & 1,500 \\
\hline As $\left(\mathrm{mg} \mathrm{kg}^{-1}\right)$ & 1.3 & $<1.0$ & 41 \\
\hline $\mathrm{B}\left(\mathrm{mg} \mathrm{kg}^{-1}\right)$ & $<1.0$ & $<1.0$ & - \\
\hline $\mathrm{Ba}\left(\mathrm{mg} \mathrm{kg}^{-1}\right)$ & 220 & 165 & 1,300 \\
\hline $\mathrm{Cd}\left(\mathrm{mg} \mathrm{kg}^{-1}\right)$ & 1.6 & 1.2 & 39 \\
\hline Co $\left(\mathrm{mg} \mathrm{kg}^{-1}\right)$ & $<1.0$ & $<1.0$ & - \\
\hline $\mathrm{Cr}\left(\mathrm{mg} \mathrm{kg}^{-1}\right)$ & 260 & 195 & 1,000 \\
\hline $\mathrm{Hg}\left(\mathrm{mg} \mathrm{kg}^{-1}\right)$ & $<1.0$ & $<1.0$ & 17 \\
\hline $\mathrm{Mn}\left(\mathrm{mg} \mathrm{kg}^{-1}\right)$ & 387 & 290 & - \\
\hline Mo $\left(\mathrm{mg} \mathrm{kg}^{-1}\right)$ & 1.2 & $<1.0$ & 50 \\
\hline $\mathrm{Ni}\left(\mathrm{mg} \mathrm{kg}^{-1}\right)$ & 54.6 & 41.5 & 420 \\
\hline $\mathrm{Pb}\left(\mathrm{mg} \mathrm{kg}^{-1}\right)$ & 26.3 & 19.7 & 300 \\
\hline Se $\left(\mathrm{mg} \mathrm{kg}^{-1}\right)$ & $<1.0$ & $<1.0$ & 100 \\
\hline $\mathrm{Sb}\left(\mathrm{mg} \mathrm{kg}^{-1}\right)$ & $<1.0$ & $<1.0$ & - \\
\hline $\mathrm{Zn}\left(\mathrm{mg} \mathrm{kg}^{-1}\right)$ & 690 & 517 & 2,800 \\
\hline
\end{tabular}

aMaximum concentration allowed in sewage sludge or derivative by CONAMA, 2006a.

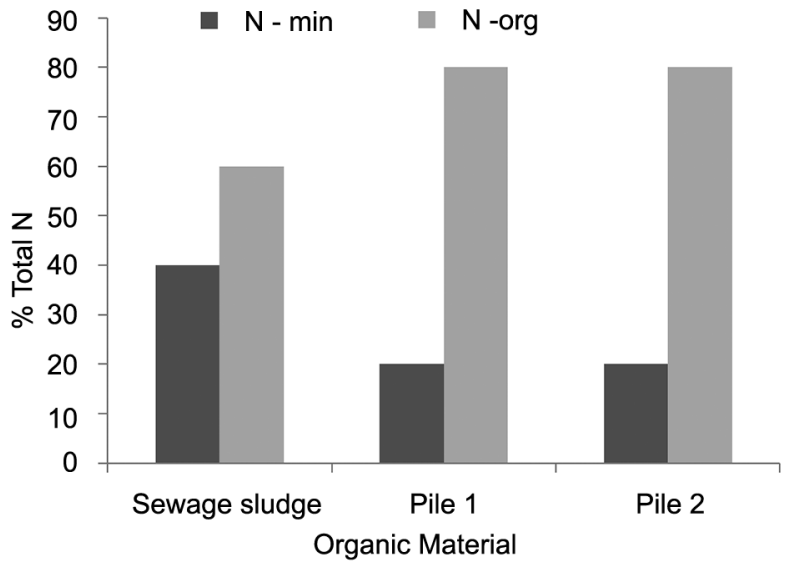

Figure 3 - Distribution of forms of $\mathrm{N}$ (N-min, $\mathrm{N}$ in mineral form; N-org, $\mathrm{N}$ in organic form) in the sewage sludge and compost (Pile 1 and Pile 2).

\section{Binomial time-temperature and decay of pathogens during the composting process}

The thermophilic phase is characterised by temperatures above $55^{\circ} \mathrm{C}$ as was observed in the two composting piles from day 15 until day 35 (Figure 4). Tem- peratures above $60{ }^{\circ} \mathrm{C}$ were observed in both piles for eight non-consecutive days. After 80 days the temperature of piles remained constant (below $50{ }^{\circ} \mathrm{C}$ ) until 120 days and the composting process was continued until 140 days to make sure that the parameters which indicate the maturation of organic material remained constants.

Brazilian environmental legislation (CONAMA, 2006b) states that the temperature of the pile should be maintained above $40{ }^{\circ} \mathrm{C}$ for at least 14 days, and the average temperature during this period must be higher than $45^{\circ} \mathrm{C}$ for sewage sludge disinfection. Also, according to the USEPA (2003), to reduce pathogens to a level that poses negligible risk to humans and environmental risk, all particles of the composted mass must be exposed to temperatures above $55^{\circ} \mathrm{C}$ for a period of at least 3 days in static systems and for 15 days in mechanical turning systems. Thus, the binomial time-temperature obtained in this study would be sufficient for disinfection of the sanitary sludge.

Jouraiphy et al. (2005) observed a significant reduction in the quantities of clostridia in the early months of composting sewage sludge with plant residues; a reduction in bacilli and yeasts was observed when the temperatures were between 60 and $70{ }^{\circ} \mathrm{C}$, 
and after 135 days. Fernández et al. (2010) and Khalil et al. (2011) observed that high temperatures were able to reduce or eliminate pathogenic microorganisms present in the sludge.

The amount of total coliforms and Escherichia coli present in sewage sludge was $10^{7}$ and $10^{6} \mathrm{MPN}$ per gram of dried sludge, respectively, which decreased during the composting process to $10^{4}$ and $10^{3}$ of total coliforms per gram of dried compost for piles 1 and 2 , respectively (Table 2 ). These values are in agreement with those stipulated by Brazilian agricultural legislation (MAPA, 2006) and environmental legislation (CONAMA, 2006a).

Total coliform and $E$. coli decay were adjusted to quadratic regression models (Table 2), since after 90 days of the composting process, an increase in the amount of faecal coliforms was observed in Pile 1. This was probably because the piles were irrigated with reused water, which had $<100 \mathrm{MPN} \mathrm{L}^{-1}$ of total coliforms and $<100$ MPN L ${ }^{-1}$ of $E$. coli, which caused recontamination of the material by the external source and/or regrowth of $E$. coli (Turner, 2002; Khalil et al., 2011), since the amount of $E$. coli present in the material was almost equal to the total amount of fecal coliforms (Table 2). Irrigation of the piles with reused water increased the amount of fecal coli- forms after the thermophilic stage of the process. Hassen et al. (2001) stated that secondary growth of fecal coliforms was found during composting, and they attributed this to a recontamination of the material during handling and storage of the product. However, this growth did not occur in all piles, similar to that observed by Khalil et al. (2011), in a study performed with four piles of composting, in which only two piles had recontamination. This effect was attributed by Khalil et al. (2011) to different volumes of reuse water used for irrigation of piles, causing a variation in the amount of coliforms.

Salmonella and protozoan cysts were not observed in $10 \mathrm{~g}$ of dry matter, sewage sludge or compost. However, in studies conducted in the presence of Salmonella, Wichuk and McCartney (2008) found that when the temperature is kept at $55{ }^{\circ} \mathrm{C}$ for three days, the levels of Salmonella can be reduced to levels below the detection limit.

The lot of sewage sludge used in the composting process had around 0.6 viable helminth egg per gram dry sludge (Table 3), a value $120 \%$ above that stipulated by Brazilian environmental legislation (CONAMA, 2006a) and agricultural legislation (MAPA, 2006), a factor that classifies it as class B according to Brazilian environmental legislation. The composting process provided
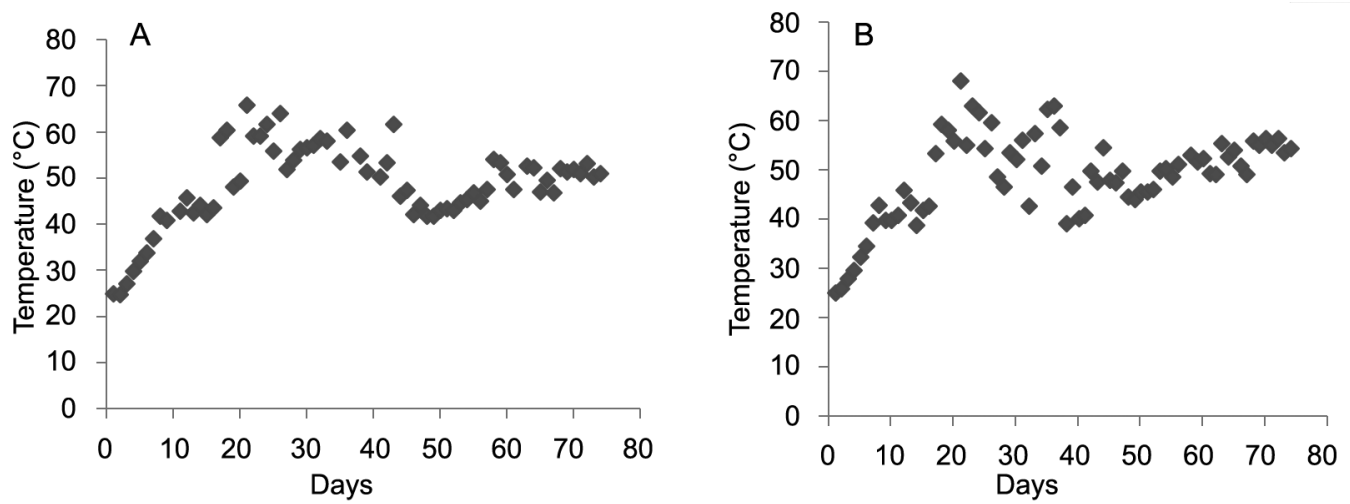

Figure 4 - Change in temperatures of Pile $1(A)$ and Pile $2(B)$ during the composting process until the cooling down phase.

Table 2 - Quantification of total coliforms and Escherichia coli during the composting process.

\begin{tabular}{|c|c|c|c|c|}
\hline Material & Days & Water content & Total coliforms & E. coli \\
\hline & & $\%$ & $\mathrm{MPN}^{\mathrm{a}}$ & total solids \\
\hline Sewage sludge & 0 & 78 & $4.4 \times 10^{7}$ & $1.2 \times 10^{6}$ \\
\hline Pile 1 & \multirow{2}{*}{30} & 56 & $5.5 \times 10^{5}$ & $2.8 \times 10^{5}$ \\
\hline Pile 2 & & 46 & $7.6 \times 10^{5}$ & $5.5 \times 10^{5}$ \\
\hline Pile 1 & \multirow{2}{*}{60} & 53 & $4.61 \times 10^{5}$ & $<1.0 \times 10^{4}$ \\
\hline Pile 2 & & 54 & $3.8 \times 10^{6}$ & $7.1 \times 10^{4}$ \\
\hline Pile 1 & \multirow{2}{*}{90} & 55 & $5.4 \times 10^{6}$ & $<1 \times 10^{3}$ \\
\hline Pile 2 & & 57 & $1.48 \times 10^{4}$ & $<1.0 \times 10^{4}$ \\
\hline Pile 1 & \multirow{4}{*}{120} & 42 & $<5.1 \times 10^{4}$ & $3.8 \times 10^{3}$ \\
\hline Pile 2 & & 55 & $<5.4 \times 10^{4}$ & $1.1 \times 10^{4}$ \\
\hline Equation & & & $y=6.3 \times 10^{3} x^{2}-10^{6} x+3.8 \times 10^{7}$ & $y=1.5 \times 10^{2} x^{2}-2.8 \times 10^{4} x+1.2 \times 10^{6}$ \\
\hline $\mathrm{R}^{2}$ & & & $0.82^{*}$ & $0.97^{\star *}$ \\
\hline
\end{tabular}

aMost Probable Number. ${ }^{*} p<0.01,{ }^{* *} p<0.001$ 
Table 3 - Viability of helminth eggs in sewage sludge and composts.

\begin{tabular}{|c|c|c|c|c|c|c|c|c|c|}
\hline \multirow{3}{*}{ Helminths } & \multicolumn{3}{|c|}{ Sludge } & \multicolumn{3}{|c|}{ Pile 1} & \multicolumn{3}{|c|}{ Pile 2} \\
\hline & Viable & Nonviable & Total & Viable & Nonviable & Total & Viable & Nonviable & Total \\
\hline & \multicolumn{9}{|c|}{ Egg per gram of total solids } \\
\hline Ascaris sp. & 0.13 & 0.4 & 0.53 & 0 & 0.23 & 0.23 & 0 & 0.08 & 0.08 \\
\hline Toxocara sp. & 0 & 0.26 & 0.26 & 0 & 0 & 0 & 0 & 0 & 0 \\
\hline Trichuris trichiura & 0 & 0 & 0 & 0 & 0 & 0 & 0 & 0 & 0 \\
\hline Trichuris vulpis & 0 & 0.04 & 0.04 & 0 & 0 & 0 & 0 & 0 & 0 \\
\hline Trichuroidea & 0.04 & 0.26 & 0.30 & 0 & 0.23 & 0.23 & 0 & 0.06 & 0.06 \\
\hline Hymenolepis diminuta & 0.43 & 0.13 & 0.56 & 0 & 0.05 & 0.05 & 0 & 0.03 & 0.03 \\
\hline Taenia sp. & 0 & 0 & 0 & 0 & 0 & 0 & 0 & 0 & 0 \\
\hline Strongyloidea & 0 & 0 & 0 & 0 & 0 & 0 & 0 & 0 & 0 \\
\hline Total & 0.6 & 1.09 & 1.69 & 0 & 0.51 & 0.51 & 0 & 0.17 & 0.17 \\
\hline$\%$ viability & 36 & & & 0 & & & 0 & & \\
\hline Protozoa & 0 & & & 0 & & & 0 & & \\
\hline
\end{tabular}

the elimination of such enteric pathogens, starting from $36 \%$ of viable eggs in the sludge to $0 \%$ in the compost (Table 3). Fecal coliform values of the compost showed an increase from 90 days (Table 2).

\section{Conclusions}

After the composting process, there was a reduction in the risk of nitrate leaching by immobilisation of mineral nitrogen to more stable organic forms in the sewage sludge compost. The final compost had a better nutrient balance, with reduced contents of $\mathrm{As}, \mathrm{B}, \mathrm{Ba}$, $\mathrm{Cr}, \mathrm{Cd}, \mathrm{Cu}, \mathrm{Hg}, \mathrm{Mo}, \mathrm{Ni}, \mathrm{Pb}, \mathrm{Se}, \mathrm{Sb}$, and $\mathrm{Zn}$, although the content in the sewage sludge was already below the limit required by legislation. Furthermore, the values of fecal coliform were reduced at the end of the composting process, and viable eggs were eliminated.

\section{Acknowledgements}

This research was funded by the Brazilian National Council for Scientific and Technological Development (CNPq), process $n^{\circ} 575025 / 2008-5$. The master's scholarship was funded by the Coordination for the Improvement of Higher Level Personnel (CAPES). The logistical support in composting process was supplied by the sewage treatment station of the Basic Sanitation Company of the State of São Paulo (SABESP), located in the city of Franca, São Paulo, Brazil.

\section{References}

Amir, S.; Hafidi, M.; Merlina, G.; Revel, J. 2005. Sequential extraction of heavy metals during composting of sewage sludge. Chemosphere 59: 801-810.

Andrade, J.C.; Abreu, M.F. 2006. Chemical analysis of solid waste for monitoring and agri-environmental studies = Análise química de resíduos sólidos para monitoramento e estudos agroambientais. p. 121-158. In: Andrade, J.C.; Falcão, A.A.; Abreu, M.F., eds. Protocols for chemical analysis. Instituto Agronômico, Campinas, SP, Brazil (in Portuguese).
Association of Official Analytical Chemists - International [AOAC]. 1984. Official Methods of Analysis. 14ed. AOAC, Gaithersburg, MD, USA.

Bertoncini, E.I.; Mattiazzo, M.E.; Rossetto, R. 2004. Sugarcane yield and heavy metal availability in two biosolid-amended Oxisols. Journal of Plant Nutrition 7: 1243-1260.

Bertoncini, E.I.; D'Orazio, V.; Senesi, N.; Mattiazzo, M.E. 2008. Effects of sewage sludge amendment on the properties of two Brazilians oxisols and their humic acids. Bioresource Technology 99: 4972-4979.

Cai, Q.Y.; Mo, C.H.; Wu, Q.T.; Zeng, Q.Y.; Katsoyiannis, A.; Ferard, J.F. 2007. Bioremediation of polycyclic aromatic hydrocarbons (PAHs)-contaminated sewage sludge by different composting processes. Journal of Hazardous Materials 142: 535-542.

Corrêa, R.S.; White, R.E.; Weatherley, A.J. 2006. Effect of compost treatment of sewage sludge on nitrogen behavior in two soils. Waste Management 26: 614-619.

Environmental National Council [CONAMA]. 2006a. Resolution $n^{\circ} 375$ of 29 August 2006. Provides criteria and procedures for sewage sludge agricultural use produced in sanitary sludge treatment plant and their derivatives $=$ Define critérios $\mathrm{e}$ procedimentos, para o uso agrícola de lodos de esgoto gerados em estações de tratamento de esgoto sanitário e seus produtos derivados, e dá outras providências. Available at: http://www. mma.gov.br/port/conama/res/res06/res37506.pdf [Accessed Jan 20, 2013] (in Portuguese).

Environmental National Council [CONAMA]. 2006b. Resolution $\mathrm{n}^{\circ} 380$ of 29 August 2006. Rectifies the Resolution CONAMA $n^{\circ} 375 / 2006$ - Provides criteria and procedures for agricultural use of sewage sludge produced in sanitary sludge treatment plant and other measures $=$ Retifica a Resolução CONAMA n ${ }^{\circ}$ 375/2006 - Define critérios e procedimentos para o uso agrícola de lodos de esgoto gerados em estações de tratamento de esgoto sanitário e seus produtos derivados, e dá outras providências. Available at: http://www.mma.gov.br/port/conama/legislacao/ CONAMA_RES_CONS_2006_380.pdf [Accessed Jan 20, 2013] (in Portuguese).

European Commission. 2001. Disposal and recycling routes for sewage sludge. Part 1 . Sludge use acceptance report. Office for Official Publications of the European Communites, Luxembourg City, Luxembourg. 
Fernández, F.J.; Sánchez, V.; Rodríguez, L.; Villaseñor, J. 2010. Feasibility of composting combinations of sewage sludge, olive mill waste and winery waste in a rotary drum reactor. Waste Management 30: 1948-1956.

Gaines, T.P. 1977. Determination of protein nitrogen in plants. Journal of AOAC International 60: 590-593.

Gaspard, P.; Wiart, J.; Schwartzbrod J. 1997. Parasitological contamination of urban sludge used for agricultural purposes. Waste Management \& Research 15: 429-436.

Gerba, C.P.; Smith, J.E. 2005. Sources of pathogenic microorganisms and their fate during land application of wastes. Journal of Environmental Quality 34: 42-48.

Hassen, A.; Belguith, K.; Jedidi, N.; Cherif, A.; Cherif, M.; Boudabous, A. 2001. Microbial characterization during composting of municipal solid waste. Bioresource Technology 80: $217-225$.

Hernández, T.; Masciandaro, G.; Moreno, J.I.; García, C. 2006. Changes in organic matter composition during composting of two digested sewage sludges. Waste Management 26: 1370-1376.

Hua, L.; Wu, W.; Liu, Y.; McBride, M.B.; Chen, Y. 2009. Reduction of nitrogen loss and $\mathrm{Cu}$ and $\mathrm{Zn}$ mobility during sludge composting with bamboo charcoal amendment. Environmental Science Pollution Research International 16: 1-9.

Jouraiphy, A.; Amir, S.; Gharous, M.; Revel, J.C.; Hafidi, M. 2005. Chemical and spectroscopic analysis of organic matter transformation during composting of sewage sludge and green plant waste. International Biodeterioration \& Biodegradation 56: 101-108.

Khalil, A.I.; Hassouna, M.S.; El-Ashqar, H.M.A.; Fawzi, M. 2011. Changes in physical, chemical, and microbial parameters during the composting of municipal sewage sludge. World Journal of Microbiology and Biotechnology 27: 2359-2369.

Melo, W.J.; Aguiar, P.S.; Melo, G.M.; Melo, V.P. 2007. Nickel in a tropical soil treated with sewage sludge and cropped with maize in a long-term field study. Soil Biology and Biochemistry 39: 1341-1347.

Méndez, A.; Gómez, A.; Paz-Ferreiro, J.; Gascó, G. 2012. Effects of sewage sludge biochar on plant metal availability after application to a Mediterranean soil. Chemosphere 11: 13541359.

Ministry of Agriculture, Livestock and Food Supply [MAPA]. 2006. Normative Instruction $n^{\circ} 27$ of 23 July 2009. Establishes limits for fertilizers, liming, and bio-inoculants, to be produced, imported or sold, in accordance with limits of annexes I, II, III, IV and V of this instruction as regards the maximum concentrations allowed for phytotoxic agents, pathogenic to man, animals and plants, toxic heavy metals, pests and weeds = Estabelece limites para fertilizantes, calcários, e bioinoculantes, a ser produzido, importado ou vendido, de acordo com os limites dos anexos I, II, III, IV e V desta instrução, no que se refere às concentrações máximas permitidas para agentes fitotóxicos, patogênicos ao homem, animais e plantas, metais pesados tóxicos, pragas e plantas daninhas. Available at: http:// sistemasweb.agricultura.gov.br/sislegis/action/detalhaAto.do $?$ method $=$ gravarAtoPDF\&tipo $=$ INM\&numeroAto $=0000002$ $7 \&$ seqAto $=000 \&$ valorAno $=2006 \&$ orgao $=$ SDA $/$ MAPA \& $\operatorname{codT}$ ipo $=\&$ desItem $=\&$ desItemFim $=[$ Accessed Jan 20, 2013] (in Portuguese).
Ministry of Agriculture, Livestock and Food Supply [MAPA]. 2009. Normative Instruction $n^{\circ} 25$ of 23 July 2009. Approves the rules on specifications and warranties, tolerances, registrations, packaging, and labeling of simple organic fertilizers, mixed organic fertilizer, compost organic fertilizers, organo-mineral fertilizer and biofertilizer for agriculture. = Aprova as regras relativas às especificações e às garantias, às tolerâncias, aos registros à embalagem e à rotulagem dos fertilizantes orgânicos, simples, mistos, compostos, organominerais e biofertilizantes destinados à agricultura. Available at: http://sistemasweb. agricultura.gov.br/sislegis/action/detalhaAto.do?method = grava rAtoPDF\&tipo $=I N M \&$ numeroAto $=00000025 \&$ seqAto $=000 \& \mathrm{~V}$ alorAno $=2009 \&$ orgao $=$ SDA $/$ MAPA $\& \operatorname{codTipo}=\&$ desItem $=\& d$ esItemFim $=$ [Accessed Sept 20, 2013] (in Portuguese).

Redshaw, C.H.; Cooke, M.P.; Talbot, H.M.; McGrath, S.; Rowland, S.J. 2008. Low biodegradability of fluoxetine $\mathrm{HCl}$, diazepam and their human metabolites in sewage sludge- amended soil. Journal of Soils and Sediments 8: 217-230.

Sarruge, J.R.; Haag, H.P. 1974. Chemical Analysis in Plants = Análise Química em Plantas. ESALQ-USP, Piracicaba, SP, Brazil. (in Portuguese).

Singh, R.P.; Agrawal, M. 2008. Potential benefits and risks of land application of sewage sludge. Waste Management 28: 347-358.

Stentiford, E.; De Bertoldi, M. 2010. Composting: process. p. 513-532. In: Christensen, T.H., ed. Solid waste technology \& management. John Wiley, Chichester, UK.

Stumpe, B.; Marschner, B. 2007. Long-term sewage sludge application and wastewater irrigation on the mineralization and sorption of 17 beta-estradiol and testosterone in soils. Science of the Total Environmental 374: 282-291.

Thomaz-Soccol, V.; Paulino, R.C.; Castro, E.A. 2000. Parasitological analysis methodology $=$ Metodologia de análise parasitológica. $\mathrm{p}$. 27-41. In: Andreoli, C.V.; Bonnet, B.R.P., eds. Manual of methods for microbiological and parasitological analysis in agricultural recycling of sewage sludge. SANEPAR, Curitiba, PR, Brazil. (in Portuguese).

Turner, C. 2002. The thermal inactivation of E.coli in straw and pig manure. Bioresource Technology 84: 57-61.

United States Environmental Protection Agency [USEPA]. 1994. SW846: Method 3051; Microwave Assisted Digestion of Sediments, Sludges, Soils, and Oils. USEPA, Washington, DC, USA.

United States Environmental Protection Agency [USEPA]. 2003. Control of Pathogens and Vector Attraction in Sewage Sludge. USEPA, Washington, DC, USA.

Walkley, A.; Black, I.A. 1934. An examination of Degtjareff method for determining soil organic matter and proposed modification of the chromic acid titration method. Soil Science 37: 29-38.

Walter, I.; Martínez, F.; Cala, V. 2006. Heavy metal speciation and phytotoxic effects of three representative sewage sludges for agricultural uses. Environmental Pollution 139: 507-514.

Wang, X.; Chen, T.; Ge, Y.; Jia, Y. 2008. Studies on land application of sewage sludge and its limiting factors. Journal of Hazardous Materials 160: 554-558.

Wichuk, K.M.; McCartney, D. 2008. A review of the effectiveness of current time: temperatures regulations on pathogen inactivation during composting. Journal of Environmental Engineering Science 6: 573-586.

Williams, S. 1984. Official Methods of Analysis of the Association of Official Analytical Chemists. 14ed. AOAC, Gaithersburg, MD, USA. 